\title{
Creative cultural tourism as a new model of the relationship between cultural heritage and tourism
}

\author{
Mukhles M. Al-Ababneh \\ Associate Professor in Hospitality and Tourism Management \\ Department of Hotel and Tourism Management, Petra College for Tourism and Archaeology, Al-Hussein Bin Talal \\ University, Jordan \\ mukhles.ababneh@gmail.com
}

DOI: https://doi.org/10.31559/IJHTS2020.1.1.4

\begin{abstract}
:
The current study explores creative cultural tourism as a new model of the relationship between cultural heritage and tourism. Cultural heritage with its tangible and intangible components represents an essential part of culture tourism. Many changes have been happened in tourism due to new forms of consumption patterns, tourism activities, and tourism products. These changes require shifting from traditional culture tourism to creative cultural tourism as a new concept of cultural heritage. Tourists face many problems in the traditional culture tourism which is a form of mass tourism, thus, creative cultural tourism came to solve these problems. In addition, this study explains the transformation from traditional culture tourism to creative culture tourism.
\end{abstract}

\section{Keywords: Culture Tourism; Cultural Heritage; Creative Cultural Tourism.}

\section{Introduction}

Many cultural and heritage destinations around the world which cannot compete based on of their resources, cultural tourism in these destinations transformed to creative cultural tourism (Florida, 2002). The term 'creative tourism' has been emerged as a new concept in tourism in many destinations around the world by reproducing and extending of cultural tourism in creative forms that leads to create creative tourism (Richards and Wilson, 2006). Redeveloping culture is a complicated process that requires some changes in creating a cultural environment that related to life style, tourism and consumption (Zukin, 1995). In many destinations the value of cultural tourism was undermined by cultural tourism because it has become subject to a vicious cycle of overdevelopment, lack of investment and reducing returns (Russo, 2002). Tourism based on its symbolic content became as part of the cultural economy (Gibson and Kong, 2005).

Creativity can add more values to destinations due to creative tourism has more potential for destinations than traditional cultural tourism (Tan, Luh and Kung, 2014). Tourism has become as one of the important drivers of creative industries by developing of tourism sites environment and repackaging of tourism services to create tourist experiences (Lash and Urry, 1994). Thus, producing innovative and flexible tourism experience (Alvarez, 2010) by shifting from cultural tourism to creative tourism development and strategies (D'Auria, 2009). With increasing supply of cultural products which outstripped demand, thus the creative tourism products development became evident in cultural tourism (Richards, 1996). Creative tourism involves creative people in tourism activities, creative products as tourism attractions, creative process in tourism activities, and creative environment in tourism sites (Florida, 2002). This research was designed to better understand the transformation to creative cultural tourism.

\section{Literature Review}

\subsection{Culture Tourism}

Culture is considered as one of the most complex words, and therefore it is difficult to define the concept of 'culture' (Williams, 1976). Herder (1774) described culture as distinctive ways of life rather than a universal value, and each people (linguistic community, ethnic group, society) have their distinctive a way of life including traditions, lifestyle, and common customs. Recently, cultural theorists defined culture as a plural concept which recognises the diversity among the different cultures. The word culture is created by interconnecting of varied local cultures, and these are all becoming sub-cultures among locals, and therefore everyone can participate in many cultures (Hannerz, 1990). 
The term 'cultural tourism' is emerged from a combination of two concepts 'culture' and 'tourism', it is considered as one of the most desirable developments in tourism in many countries around the world by the end of the $20^{\text {th }}$ century. Culture has become an important element of the tourism industry, cultural tourism is one of the largest types of tourism in the world that based on heritage or arts such as events, festivals, theatre, opera, and art exhibitions may take place in heritage streets or places, ancient amphitheatres, and historic buildings (Zeppel and Hall, 1992). In cultural tourism, it is difficult to distinguish between the components of arts and heritage because they are complexly linked (Richards, 2001). Cultural tourism is based on the heritage and history of a tourist site, and people and their contemporary lives in that a place. Cultural tourism includes contemporary culture (a way of life) and past cultural products, and hence cultural tourism is an integration of 'arts tourism' and 'heritage tourism' (Richards, 2001). Cultural tourism contributes for 37\% of all types of tourism.

\subsection{Creative Tourism}

Creativity is one of the most complex concepts of human behaviours, and therefore there is no an agreement among scholars about the main definition of creativity because creativity has a wide range of perspectives based on its functions (Robinson, 2008). However, creativity has been defined in various ways, Amabile (1997: p.40) defined creativity as "the production of novel, appropriate ideas in any realm of human activity, from science, to the arts, to education, to business, to everyday life". Creativity can be grouped into four groups, namely: the creative product, the creative person, the creative process, and the creative environment (Taylor, 1988). Historically, creativity was linked to the creative person, later, the creative product has highly emerged in recent creativity research (Amabile, 1997). Recently, another shift appears through the contemporary emphasis on both the creativity environment and the social context, and therefore the creativity's social interpretations have been apparent in tourism (Frey, 2009; Scott, 2010).

The relationship between creativity and tourism is not new phenomena, it has taken different shapes over the time (Marques and Borba, 2017). Many cities and regions around the world used creativity as a strategy for achieving growth (Ray, 1998) due to high competition between regions and cities, commodification, globalization and knowledge development (Mommaas, 2009). In the social sciences, the 'creative turn' was developed out from the 'cultural turn' this lead to generate integration between tourism and creativity at different levels (Richards and Wilson, 2007). The new integration of culture and tourism expressing the 'creative turn' that includes cultural elements as a measurement for development and growth (Andersson and Thomsen, 2008), and this leads to the growing importance of creative tourism.

Tourism was influenced by the 'creative turn' in different ways as developing skills, tourism product and performance through integrating creative into tourism activities, and therefore tourism became a creative arena. Therefore, many areas in tourism can be extended to show more than traditional creative activities by exploring the creative performative role in tourism. Tourism has been developed to become a creative environment that includes a number of new implementations as responses to the current challenges (Al-Ababneh and Masadeh, 2019). This leads to say that the phenomenon of creativity has been stimulated by ways of production and consumption (Cloke, 2006). Creative city policy can enhance cultural assets and contribute to a shift from traditional model, and this would lead to an increase in visitors and consumption (Kakiuchi, 2016).

\subsection{Relationship between Cultural Heritage and Creative Cultural Tourism}

The development of creative production has been stimulated by creative industries strategies, it based on casual and part-time workers, and they attending events and parties in creative cultural places, and building their creative networks in order to increase their career prospects (Currid, 2007). Creativity can be attractive as a policy that stimulating social, cultural and economic outcomes, and stimulating further creative activity by achieving the advantages that produced by knowledge spillover and networking (Campbell, 2011).

The popular culture can be raised through creativity which plays a great important role in developing culture (Fiske, 1989). Tourism permits the masks of everyday to be discarded, and offering opportunities to take on new roles and to explore different identities (MacCannell, 1976), and tourism can be seen as an escape from everyday life (Graburn, 1989). Culture is a key to foster creativity, and therefore culture may refer to beliefs, artistic creation, traditions, behaviours, symbolic values and creative skills (Montalto et al., 2019). Many traditional cultures in intangible culture can be survived after the transformation to creative tourism (Tan, Kung and Luh, 2013). The view that considered tourism as an activity which is not from everyday life was a challenge in the recent research on cultural and creative tourism (Edensor, 2007). Creativity in tourism studies has been repositioned in a wide range from a narrow broader such as products of craft and arts to a much broader including many of tourism activities by analysing creativity as a force for tourism development (Al-Ababneh and Masadeh, 2019). Many studies explored the relationship between tourism and creativity by focusing on the cocreation development in tourism (Binkhorst and den Dekker, 2009).

The practices of creativity in cultural tourism help to create new identification symbols. For example, skilled consumption develops distinctive identities for people through their lifestyle enhancement, and it generate creative use of tourism resources (Richards, 1996; Russo and Aria Sans, 2007), and therefore consumption skills are an important tool to navigate the postmodern landscape (Collins, 2004). Many of the key consumption trends 
that emphasised on the important role of creativity in tourism are, namely: increased desire for skilled consumption, building narrative, biography and identity, self-development, dissatisfaction with consumption contemporary modes, blurring boundaries between leisure and work (serious leisure, lifestyle entrepreneurship, work as play), experience hunger of postmodern consumers, and creativity attractiveness as a form of expression (Richards and Wilson, 2006). Furthermore, consumption skills in the development of hobbies are usually honed during leisure time (Jelinc 'ic', 2009). Creative skills are used in tourism business, for example in gastronomic experiences, the provision of photography holidays or painting, and 'holistic' or spiritual holidays (Smith and Puczko', 2008). The role of creative industries has been increased in developing tourism and the destinations image, which are based on the interests of tourists as special interest tourists or cultural tourists make the links between creativity and tourism (Zeppel and Hall, 1992) consuming crafts products or creative performances. The local arts products had been transformed by tourist arts in tourism activities (Graburn, 1984; Boynton, 1986).

Pearce and Butler (1993) used the concept of creative tourism as a potential form of tourism for the first time, and then later, Richards and Raymond (2000: p. 18) presented the first analysis of creative tourism as a definition: "Tourism which offers visitors the opportunity to develop their creative potential through active participation in courses and learning experiences which are characteristic of the holiday destination where they are undertaken". Creative tourism emphasises on intangible culture or living rather than static, tangible cultural heritage. The creative tourism experiences and activities which are related to self-expression and self-realization, tourists develop their creative skills as co-creators and co-performers (Raymond, 2007). Sometimes a particular creative tradition can be uniqueness (Morel, 2009). Many scholars have identified a shift from cultural tourism to creative cultural tourism. For example, D'Auria (2009) argued that creative tourism is considered as an evolution of cultural tourism directed toward more engaged and authentic experiences. Jelinc ic' (2009) stated that creative activities in tourism increased by splintering of cultural tourism which are developed to meet fragmented postmodern lifestyles by tourists. Fernandez (2010) suggested that the evolution of tourism production system has been raised creative tourism models. These studies confirmed the relationship between cultural tourism and creative tourism. Culture and creativity are important factors in the development of tourism, and they are being significant contributors to economic development (Durmaz, Platt and Yigitcanlar, 2010). Thus, creative and cultural industries can be considered as driving factors of local development and economic growth (Boccella and Salerno, 2016).

In the beginning of the 21th century, creative tourism as a concept was evolved as a new form of cultural tourism by the intention to make the cultural tourism negative impacts diminish and more sustainable (Sano, 2016). Although the importance of creative cultural tourism, it can impact the quality of tourist's experience as a result of attracting a large number of tourists (Richards, 2009). Creative tourism has a higher possibility of enhancing commodification of intangible side of cultural heritage sites (Richards, 2011). The main problem of commodification is a change in the indigenous culture that follows tourism activity has made by reproducing culture (Rahman and Narendra, 2017). Thus, creative cultural tourism in historical sites requires investments for development and maintenance, significant time and expertise, and massive level of innovation and creativity, and relies on everyday lifestyle and tangible resources of cities (Richards and Wilson, 2007). Most scholars argued that there is a need for creative tourism, but there are several criticisms of it such as using creativity in tourism development may bring the tendency strengthening risk towards the life world colonization by the commerce forces, creative tourism initiatives may also be problematic when increasing contact with 'local' culture. Thus, creative tourism initiatives focus on delivering the creative experience of the tourist, the creative life of the destination, indigenous creativity and real benefits for local residents (Smith and Richards, 2013).

Although creative cultural tourism has been discussed in many recent studies, this study aims to provide some thought about creative cultural tourism as a link between cultural heritage and tourism. Furthermore, this study points out the importance of creative cultural tourism as a new model of cultural tourism through the combination between cultural heritage and creative tourism.

\section{Conclusion}

Creativity provides atmosphere, content and activity for tourism, and therefore creative activities were supported by tourism. Approaches of creative tourism may be linked to various strategies to create distinctive tourism destinations, including the creative industries promotion, and the creative class. The growing integration of tourism and creativity is evident that tourism becomes a creative industry. The development of cultural tourism can be seen as creative tourism which is an alternative to traditional cultural tourism through shifting from the tangible heritage towards the intangible culture in cultural tourism. The contextual and material forms of authenticity are important in the tangible heritage of cultural tourism, and therefore authenticity is shifting in models of creative tourism, 'authenticity' is shifting in creative tourism models.

This study contributes to understand the creative tourism, and the importance of shifting from traditional culture tourism to creative cultural tourism. The relationship between tourism and creativity may emphases on some important aspects of contemporary tourism. Creative tourism is a series of creative practices linking place, 
consumption, and production. It involves consumers, policy makers, landscapes, the creative producers, the tourists themselves, and these actors embedded creativity in tourism experiences. Recently, culture has been associated with tourism as a new theme of tourism for generating more jobs and income, and therefore many tourism destinations around the world have turned to culture to distinguish themselves from their competitors by creating more impressive and more distinctive cultural developments. Thus, cultural tourism become one of the major forms in tourism development and one of the major trends in the global tourism was the growth of cultural tourism in the future, and therefore supplying the cultural attractions grew faster than the demand on cultural tourism. More cities or regions have been encouraged to use a combination of tourism and culture after the success of cultural development strategies by using culture as a form of valorization by cities and regions, creating new distinguished cultural signs to represent the real cultural capital in an crowded marketplace, and finding a new means of cultural development for places which lacked the built heritage or iconic architecture. As a result, creativity was used in cultural places by adding cultural development, which helps these places shine on the global tourism as an alternative to cultural development in places which lacked culture resources to compete effectively in the cultural arena such as a shift from cultural attractions towards intangible atmosphere to create the attractiveness of places.

\section{References:}

[1] Al-Ababneh, M. \& Masadeh, M. (2019). "Creative cultural tourism as a new model for cultural tourism". Journal of Tourism Management Research. 6(2):109-118, https://doi.org/10.18488/journal.31.2019.62.109.118.

[2] Alvarez, M. D. (2010). "Creative cities and cultural spaces: New perspectives for city tourism". International Journal of Culture, Tourism and Hospitality Research. 4(3):171-175, https://doi.org/10.1108/17506181011067565.

[3] Amabile, T. M. (1997). "Motivating creativity in organisation: On doing what you love and loving what you do". California Management Review. 40(1): 39-58, https://doi.org/10.2307/41165921.

[4] Andersson, L. \& Thomsen, B. S. (2008). "Performative experiments and cultural replanning- Recapturing the spectacle of the city". Nordic Journal of Architectural Research. 20:39-51.

[5] ATLAS. (2011). "ATLAS cultural tourism research project". www.tram-research.-com/atlas.

[6] Binkhorst, E. \& den Dekker, T. (2009). "Agenda for co-creation tourism experience research". Journal of Hospitality Marketing and Management. 18(2-3): 311-327, https://doi.org/10.1080/19368620802594193

[7] Boccella, N. \& Salerno, I. (2016). "Creative economy, cultural industries and local development". Procedia- Social and Behavioral Sciences. 223:291-296, https://doi.org/10.1016/j.sbspro.2016.05.370.

[8] Boynton, L. L. (1986). "The effect of tourism on Amish quilting design". Annals of Tourism Research. 13(3):451-465, https://doi.org/10.1016/0160-7383(86)90030-7.

[9] Campbell, P. (2011). "You say 'creative', and I say 'creative'”. Journal of Policy Research in Tourism, Leisure and Events. 3(1):18-30, https://doi.org/10.1080/19407963.2011.539379.

[10] Cloke, P. (2006). Rurality and creative nature-culture connections. In H. Clout (Ed.), Contemporary rural geographies: Land, property and resources in Britain: Essays in Honour of Richard Munton (pp. 96-110). Routledge: London.

[11] Collins, R. (2004). Interaction ritual chains. University Press: Princeton.

[12] Currid, E. (2007). The Warhol economy: How fashion, art, and music drive New York city. University Press: Princeton.

[13] D'Auria, A. (2009). "Urban cultural tourism: Creative approaches for heritage-based sustainable development". International Journal of Sustainable Development. 12(2-3-4):275-289, https://doi.org/10.1504/ijsd.2009.032782.

[14] Durmaz, B.; Platt, S. \& Yigitcanlar, T. (2010). "Creativity, culture tourism and place-making: Istanbul and London film industries". International Journal of Culture. Tourism and Hospitality Research, 4(3):198-213, https://doi.org/10.1108/17506181011067592.

[15] Edensor, T. (2007). "Mundane mobilities, performances and spaces of tourism". Social and Cultural Geography. 8(2):199-215, https://doi.org/10.1080/14649360701360089.

[16] Fernandez, T. (2010). "More than sun, beach and heritage: Innovating Mediterranean tourism through creative tourism. Interactions, co-operation, competitiveness and economic development". 2010 RESER Conference papers. Gothenburg, Sweden.

[17] Fiske, J. (1989). Understanding Popular Culture. Routledge: London.

[18] Florida, R. (2002). The Rise of the Creative Class: And How it's Transforming Work, Leisure, Community and everyday Life. Basic Books: New York.

[19] Frey, O. (2009). Creativity of places as a resource for cultural tourism. In G. Maciocco S. Serreli (Eds.), Enhancing the city, urban and landscape perspectives, 6:135-154. Springer: Berlin. 
[20] Gibson, C. \& Kong, L. (2005). “Cultural economy: A critical review”. Prog Hum Geogr. 29:541-561.

[21] Graburn, N. H. H. (1984). The evolution of tourist arts. Annals of Tourism Research. 11(3): 393-419, https://doi.org/10.1016/0160-7383(84)90029-x.

[22] Graburn, N. H. H. (1989). Tourism: The sacred journey. In V. Smith (Ed.), Hosts and guests: The anthropology of tourism (pp. 21-36). University of Pennsylvania Press: Philadelphia.

[23] Hannerz, U. (1990). 'Cosmopolitans and locals in world culture', in Featherstone, M. (ed.) Global Culture: Nationalism, Globalisation and Modernity, Sage: London, pp. 237-252.

[24] Herder, J.G. (1969). Herder on Social and Political Culture, ed. and trans. F.M. Barnard. Cambridge University Press: Cambridge.

[25] Jelinc`ic', D. A. (2009). "Splintering of tourism market: New appearing forms of cultural tourism as a consequence of changes in everyday lives". Collegium Antropologicum, 33(1):259-266.

[26] Kakiuchi, E. (2016). “Culturally creative cities in Japan: Reality and prospects”. City, Culture and Society. 7(2):101-108, https://doi.org/10.1016/j.ccs.2015.11.003.

[27] Lash, S. \& Urry, J. (1994). Economies of Signs and Space. Sage: London.

[28] MacCannell, D. (1976). The Tourist: A New Theory of the Leisure Class. Schocken books: New York.

[29] Marques, L. \& Borba, C. (2017). “Co-creating the city: Digital technology and creative tourism”. Tourism Management Perspectives. 24:86-93, https://doi.org/10.1016/j.tmp.2017.07.007.

[30] Mommaas, H. (2009). "City, culture and identity: The city as third space". Paper presented at the Cultural Policy and Management Conference, Istanbul Bilgi University.

[31] Montalto, V., Moura, C.J.T., Langedijk, S. \& Saisana, M. (2019). “Culture counts: An empirical approach to measure the cultural and creative vitality of European cities". Cities. 89:167-185, https://doi.org/10.1016/j.cities.2019.01.014.

[32] Morel, H. (2009). "The turn of inheritance in tango: Official policies, tourism, dance championship in the city of Buenos Aires". Cuadernos de Antropología Social. 30:155-172.

[33] Pearce, D. G. \& Butler, R. W. (1993). Tourism Research: Critiques and Challenges. Routledge: London.

[34] Rahman, D. \& Narendra, A. (2017). Is creative tourism damaging heritage sites? A case study of Tenganan Pegringsingan village, Bali, Indonesia. In: Silver C., Marques L., Hanan H., Widiastuti I. (eds) Proceedings of the $6^{\text {th }}$ International Conference of Arte-Polis. Springer, Singapore.

[35] Ray, C. (1998). "Culture, intellectual property and territorial rural development". Sociologia Ruralis. 38(1):3-20, https://doi.org/10.1111/1467-9523.00060.

[36] Raymond, C. (2007). Creative tourism New Zealand: The practical challenges of developing creative tourism. In G. Richards \& J. Wilson (Eds.), Tourism, creativity and development (pp. 145-157). Routledge: London.

[37] Richards, G. (1996). Cultural Tourism in Europe. CABI: Wallingford.

[38] Richards, G. (2001). The development of cultural tourism in Europe. in Richards G. (ed.) Cultural Attractions and European Tourism. CABI: Wallingford, pp. 3-29.

[39] Richards, G. (2009). Tourism development trajectories- from culture to creativity? Asia Pacific creativity forum on culture and tourism, 3-5 June 2009, Jeju Island, South Korea.

[40] Richards, G. (2011). "Creativity and tourism - The state of the art”. Annals of Tourism Research. 38(4): $1225: 1252$.

[41] Richards, G. \& Raymond, C. (2000). “Creative tourism”. ATLAS News. 23:16-20.

[42] Richards, G. \& Wilson, J. (2006). "Developing creativity in tourist experiences: A solution to the serial reproduction of culture?” Tourism Management. 27:1209-1223, https://doi.org/10.1016/j.tourman.2005.06.002.

[43] Richards, G. \& Wilson, J. (2007). Tourism, Creativity and Development. Routledge: London.

[44] Robinson, J. R. (2008). "Webster's Dictionary definitions of creativity". Online Journal of Workforce Education and Development. 3(2): 2 .

[45] Russo, A. P. (2002). "The vicious circle of tourism development in heritage cities". Annals of Tourism Research. 29(1):165-182, https://doi.org/10.1016/s0160-7383(01)00029-9.

[46] Russo, A. P. \& Aria Sans, A. (2007). Student communities as creative landscapers: Evidence from Venice. In G. Richards and J. Wilson (Eds.), Tourism, creativity and development (pp. 161-177). Routledge: London.

[47] Sano, H. (2016). "Theoretical consideration on creative tourism". Journal of Global Tourism Research. 1(2): 127-132, https://doi.org/10.37020/jgtr.1.2_127.

[48] Scott, A. J. (2010). "Cultural economy and the creative field of the city". Geografiska Annaler: Series B, Human Geography. 92:115-130. 
[49] Smith, M. \& Puczko', L. (2008). Health and Wellness Tourism. Butterworth-Heinemann: Oxford.

[50] Smith, M. and Richards, G. (2013). The Routledge Handbook of Cultural Tourism. Routledge: London.

[51] Tan, S.-K.; Kung, S.-F. and Luh, D.-B. (2013). "A model of creative experience in creative tourism". Annals of Tourism Research. 41: 153-174, https://doi.org/10.1016/j.annals.2012.12.002.

[52] Tan, S.-K.; Luh, D.-B. \& Kung, S.-F. (2014). “A taxonomy of creative tourists in creative tourism”. Tourism Management, 42: 248-259, https://doi.org/10.1016/j.tourman.2013.11.008.

[53] Taylor, C. (1988). Various approaches to and definitions of creativity. In R. J. Sternberg (Ed.), The nature of creativity: Contemporary psychological perspectives (pp. 99-121). Cambridge Utni. Press: Cambridge, MA.

[54] Williams, R. (1976). Keywords. Fontana: London.

[55] Zeppel, H. \& Hall, C.M. (1992). 'Arts and heritage tourism', in Weiler B., Hall C.M. (eds) Special Interest Tourism 47-65, Belhaven Press: London.

[56] Zukin, S. (1995). The Cultures of Cities. Blackwell: Malden. 